\title{
MODEL REGRESI SPASIAL LAG PADA KASUS PENYAKIT DEMAM BERDARAH DENGUE (DBD) DI SUMATRA UTARA TAHUN 2016
}

\author{
EVAN ILHAM ZULHERI, YUDIANTRI ASDI, HAZMIRA YOZZA \\ Program Studi S1 Matematika, \\ Fakultas Matematika dan Ilmu Pengetahuan Alam, Universitas Andalas, \\ Kampus UNAND Limau Manis Padang, Indonesia. \\ email : evanzh1234@gmail.com
}

Diterima 22 Juni 2019 Direvisi 6 Juli 2019 Dipublikasikan 4 Agustus 2019

\begin{abstract}
Abstrak. Regresi spasial adalah regresi yang melibatkan pengaruh spasial. Regresi spasial lag adalah suatu pendekatan pada analisis regresi spasial. Pada penelitian ini model regresi spasial lag digunakan untuk memodelkan data penyakit demam berdarah dengue (DBD) di provinsi Sumatra Utara. Pemodelan ini didahului oleh pengujian autokorelasi spasial dengan uji moran I. Diperoleh bahwa terjadi autokorelasi pada data penyakit demam berdarah dengue (DBD) di provinsi Sumatra Utara dan didapatkan model sebagai berikut:

$$
y=-412,053+0,246971 \mathbf{W} y+7,91774 x_{2}+2,59216 x_{3}+3,23628 x_{4} .
$$

Pada model dapat dijelaskan bahwa jika nilai pada $X_{2}$ (tingkat kemiskinan) naik $1 \%$ maka banyak penderita DBD di daerah tersebut akan bertambah 7,91774 orang, jika nilai pada $X_{3}$ (perilaku hidup bersih) naik $1 \%$ maka banyak penderita DBD di daerah tersebut akan bertambah 2,59216 orang dan pada nilai $X_{4}$ (akses sanitasi) naik $1 \%$ maka banyak penderita DBD di daerah tersebut akan bertambah 3,23628 orang. Jika penderita DBD di suatu daerah bertambah 1 orang, maka hal ini akan menambah jumlah penderita DBD di daerah-daerah yang bertetangga dengannya sebesar 0,246971 orang.
\end{abstract}

Kata Kunci: Regresi spasial lag, uji moran I, Autokorelasi

\section{Pendahuluan}

Demam berdarah atau Demam Berdarah Dengue(DBD) adalah penyakit yang disebabkan oleh infeksi virus Dengue. Virus ini masuk ke dalam tubuh manusia melalui gigitan nyamuk Aedes aegypti dan Aedes albopictus, yang hidup di wilayah tropis dan subtropis. Diperkirakan terdapat setidaknya 50 juta kasus demam berdarah di seluruh dunia setiap tahunnya. Beberapa tahun terakhir, kasus Demam Berdarah Dengue (DBD) seringkali muncul di musim pancaroba, khususnya bulan Januari. Oleh karena itu masyarakat perlu mengetahui penyebab terjadinya penyakit DBD, mengenali tanda dan gejalanya, sehingga mampu mencegah dan menanggulangi dengan baik. 
Penyakit DBD dapat dipengaruhi oleh beberapa hal seperti, daerah yang saling berdekatan. Sehingga banyaknya penderita DBD pada suatu daerah akan mempengaruhi jumlah penderita daerah yang saling berdekatan atau bertetangga. Data penderita penyakit DBD ini dinamakan data spasial. Jika pada data spasial dimodelkan dengan analisis regresi biasa akan menghasilkan kesimpulan yang kurang tepat, sehingga haruslah dimodelkan dengan analisis regresi spasial lag.

\section{Landasan Teori}

\subsection{Autokorelasi Spasial}

Autokorelasi adalah kondisi dimana terdapat korelasi atau hubungan antar pengamatan (observasi), baik itu dalam bentuk observasi deret waktu (time series) atau observasi cross section. Autokorelasi spasial diekspresikan melalui pembobotan dalam bentuk matriks yang lebih dikenal sebagai matriks bobot spasial ( $s p a-$ tial weight matrix) yang menggambarkan kedekatan hubungan antar pengamatan. Data dikatakan spasial jika terdapat autokorelasi antar lokasi. Untuk menunjukkan apakah terdapat autokorelasi spasial digunakan uji Moran I

Pengujian Moran I digunakan untuk menguji terdapatnya autokorelasi spasial global untuk data yang kontinu. Uji Moran I dapat dilakukan terhadap residual maupun data respons. Pada pengujian ini digunakan koefisien Moran I yang dirumuskan sebagai berikut [12]:

$$
I=\frac{n}{S_{0}} \frac{\sum_{i=1}^{n} \sum_{j=1}^{n} w_{i j}\left(y_{i}-\bar{y}\right)\left(y_{j}-\bar{y}\right)}{\sum_{i}\left(y_{i}-\bar{y}\right)^{2}}
$$

Uji Moran I dilakukan dengan hipotesis:

$$
\begin{aligned}
& H_{0}: I=0, \text { (tidak ada autokorelasi antar lokasi), } \\
& H_{1}: I \neq 0, \text { (ada autokorelasi antar lokasi). }
\end{aligned}
$$

Statistik uji yang digunakan adalah :

$$
Z_{\text {hitung }}=\frac{I-I_{0}}{\sqrt{\operatorname{Var}(I)}}, \text { dimana } I_{0}=-\frac{1}{n-1} .
$$

Pengambilan keputusan $H_{0}$ ditolak jika $\left|Z_{\text {hitung }}\right|>z_{\alpha / 2}$. Nilai dari indeks I adalah antara -1 dan 1. Apabila $I>I_{0}$ maka data memiliki autokorelasi positif, jika $I<$ $I_{0}$ maka memiliki autokorelasi negatif. Atau dengan cara melihat p-value dari uji Moran I. Jika p-value nya lebih kecil dari $\alpha$ maka dapat disimpulkan bahwa terjadi autokorelasi spasial atau tolak $H_{0}$.

\subsection{Model Regresi Spasial Lag}

Analisis regresi (regression analysis) adalah metode statistik yang berguna untuk menentukan pola hubungan antara suatu variabel yang disebut sebagai variabel respons (dependent), dengan satu atau lebih variabel bebas (independent). Dalam memodelkan analisis regresi dapat dilakukan dengan metode OLS (Ordinary Least Square). Metode OLS adalah suatu metode yang digunakan untuk menduga koefisien regresi klasik dengan cara meminimumkan jumlah kuadrat galat. 
Data spasial tidak dapat dimodelkan dengan metode OLS sehingga dilakukan dengan analisis regresi spasial. Analisis regresi spasial adalah model spasial yang melibatkan pengaruhi spasial [4]. Analisis data spasial merupakan suatu analisis data untuk mendapatkan informasi pengamatan yang dipengaruhi efek ruang atau lokasi. Adanya unsur autokorelasi spasial menyebabkan terbentuknya parameter spasial autoregresive dan moving average, sehingga bentuk proses spasial yang terjadi adalah sebagai berikut.

$$
\begin{aligned}
& \mathbf{y}=\rho \mathbf{W} \mathbf{y}+\mathbf{X} \beta+u \\
& \mathbf{u}=\mu \mathbf{W} \mathbf{u}+\varepsilon
\end{aligned}
$$

dimana $\varepsilon \backsim M V N\left(0, I \sigma^{2}\right)$.

Akibatnya model umum yang terbentuk adalah:

$$
\mathbf{y}=\rho \mathbf{W} \mathbf{y}+\mathbf{X} \beta+\mu \mathbf{W} \mathbf{u}+\varepsilon .
$$

Jika pada persamaan (2.2) memperhitungkan pengaruh spasial lag pada variabel respons dinyatakan $\mu=0$, maka akan diperoleh bentuk:

$$
\mathbf{y}=\rho \mathbf{W} \mathbf{y}+\mathbf{X} \beta+\varepsilon,
$$

sehingga apabila ditulis dalam bentuk matriks maka akan diperoleh bentuk berikut:

$$
\left[\begin{array}{r}
y_{1} \\
y_{2} \\
\vdots \\
y_{n}
\end{array}\right]=\rho\left[\begin{array}{rrrr}
w_{11} & w_{12} & \ldots & w_{1 n} \\
w_{21} & w_{22} & \ldots & w_{2 n} \\
\vdots & \vdots & \ddots & \vdots \\
w_{n 1} & w_{n 2} & \ldots & w_{n n}
\end{array}\right]\left[\begin{array}{r}
y_{1} \\
y_{2} \\
\vdots \\
y_{n}
\end{array}\right]+\left[\begin{array}{rrrr}
1 & x_{11} & \ldots & x_{1 k} \\
1 & x_{21} & \ldots & x_{2 k} \\
\vdots & \vdots & \ddots & \vdots \\
1 & x_{n 1} & \ldots & x_{n k}
\end{array}\right]\left[\begin{array}{r}
\beta_{0} \\
\beta_{1} \\
\vdots \\
\beta_{k}
\end{array}\right]+\left[\begin{array}{r}
\varepsilon_{1} \\
\varepsilon_{2} \\
\vdots \\
\varepsilon_{n}
\end{array}\right] .
$$

\section{Metode Penelitian}

Data yang digunakan adalah data sekunder yang didapatkan dari Dinas Kesehatan Provinsi Sumatra Utara mengenai penyakit Demam Berdarah Dengue pada tahun 2016 untuk Kabupaten dan Kota se-Sumatera Utara. Variabel-variabel yang digunakan adalah:

(1) Variabel Respons

Variabel respons pada penelitian ini adalah banyak penderita DBD pada setiap Kabupaten/Kota di Provinsi Sumatera Utara pada tahun 2016 (Y)

(2) Variabel Bebas

Variabel bebas pada penilitian ini adalah :

(a) Kepadatan Penduduk $\left(X_{1}\right)$ Kepadatan penduduk dihitung dari jumlah penduduk suatu daerah dibagi dengan luas daerah tersebut.

(b) Persentase Kemiskinan $\left(X_{2}\right)$ Persentase kemisikinan dilihat dari banyaknya penduduk miskin berdasarkan kepadatan kepadatan penduduk suatu daerah.

(c) Perilaku Hidup Bersih $\left(X_{3}\right)$ Perilaku hidup bersih adalah perilaku yang dipraktekkan oleh setiap individu dengan kesadaran diri untuk meningkatkan kesehatan dan berperan 
aktif dalam mewujudkan lingkungan yang sehat. Persentase hidup bersih ini didapatkan dari persentase penduduk yang menerapkan hidup bersih dari seluruh penduduk pada daerah tersebut.

(d) Akses Sanitasi $\left(X_{4}\right)$

Sanitasi adalah perilaku disengaja dalam membudayakan hidup bersih dengan bermaksud mencegah manusia bersentuhan langsung dengan kotoran dan bahan limbah buangan berbahaya lainnya dengan harapan usaha ini akan menjaga dan meningkatkan kesehatan manusia. Persentase penduduk dengan akses terhadap fasilitas sanitasi (jamban sehat) menurut jenis jamban.

(e) Efisiensi Jumlah Puskesmas $\left(X_{5}\right)$

Efisiensi jumlah puskesmas ini didapatkan dari kepadatan penduduk dari suatu daerah dibagi dengan jumlah puskesmas didaerah tersebut.

Berikut adalah tahapan dalam penelitian ini.

(1) Memeriksa model regresi linier klasik dengan metode OLS.

(2) Menghitung residual model.

(3) Lakukan uji homoskedastisitas dengan menggunakan uji Breush Pangan.

(4) Lakukan uji autokorelasi spasial dengan uji Moran I.

(a) Hitung nilai matriks pembobot.

(b) Hitung nilai uji Moran I.

(c) Pengambilan keputusan mengenai autokorelasi spasial.

(5) Menentukan model regresi spasial lag :

$$
y=\rho W_{1} y+X \beta+\mu .
$$

(6) Memberikan interpretasi terhadap model regresi spasial lag yang telah didapatkan.

Pada penelitian ini digunakan Software GeoDa untuk menentukan nilai-nilai pengujian pada langkah-langkah atau tahapan penelitian.

\section{Pembahasan}

\subsection{Deskripsi Data}

Pada deskripsi data ini dilakukan scatter plot pada setiap variabel bebas terhadap variabel terikat, didapatkan:
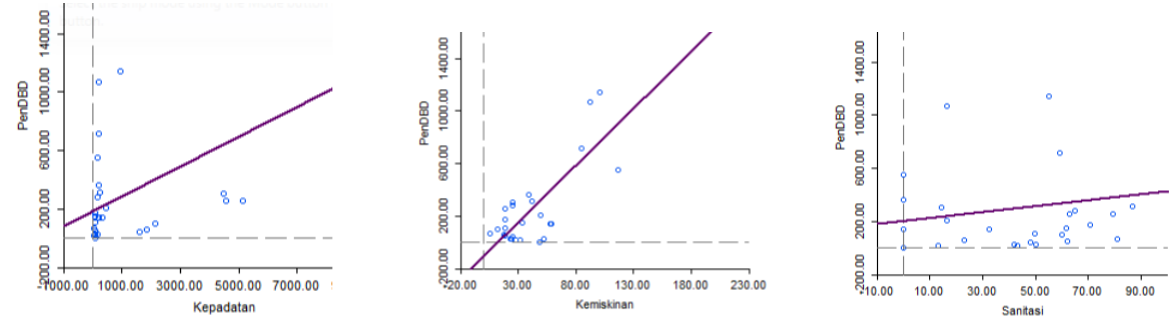

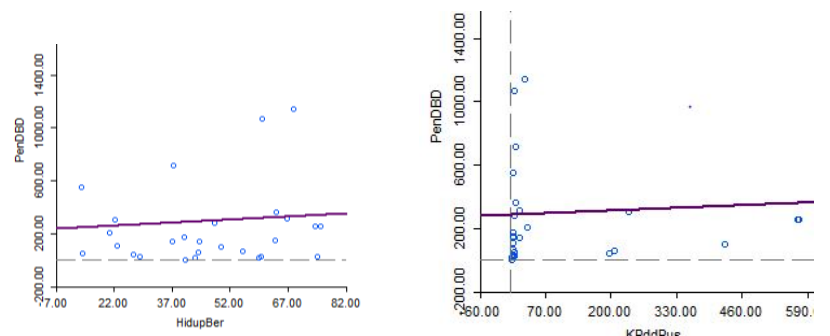

Disimpulkan bahwa pada Gambar 1 kepadatan tidak cukup terlihat terdapatnya pengaruh kepadatan penduduk terhadap jumlah penderita DBD dikarenakan kepadatan penduduk tersebut berpusat pada nilai yang sama tapi dengan jumlah penderita DBD yang berbeda. Dengan demikian dapat diperkirakan bahwa varia-bel kepadatan penduduk ini tidak mempengaruihi banyak penderita DBD dari sua-tu daerah.

Pada Gambar 2 kemiskinan terlihat adanya hubungan antara jumlah penderita DBD dengan kemiskinan dimana semakin besar persentase kemisikinan maka semakin banyak penderita DBD di daerah tersebut.

Pada Gambar 3 sanitasi semakin besar persentase masyarakat yang memiliki akses yang layak sanitasi maka semakin banyak penderita DBD. Dengan demikian dapat diduga terdapat hubungan antara jumlah penderita DBD dengan persentase masyarakat yang memiliki akses sanitasi.

Pada Gambar 4 hidup bersih dapat diduga bahwa adanya hubungan antara jumlah penderita DBD dengan perilaku hidup bersih dimana semakin besar persentase masyarakat berperilaku bersih maka jumlah penderita DBD akan semakin banyak.

Pada Gambar 5 banyaknya puskesmas sama hal nya dengan kepadatan penduduk, tidak cukup terlihat terdapatnya pengaruh efisiensi jumlah puskesmas terhadap jumlah penderita DBD dikarenakan pada efisiensi jumlah puskesmas tersebut berpusat pada nilai yang sama tapi dengan jumlah penderita DBD yang berbeda. Dengan demikian dapat diperkirakan bahwa variabel efisiensi jumlah puskesmas ini tidak mempengaruihi banyak penderita DBD dari suatu daerah.

\subsection{Uji Moran I}

Uji Moran I berguna untuk menentukan apakah pada data tersebut terjadi autokorelasi spasial. Dengan menggunakan Software GeoDa dilakukan pemeriksaan autokorelasi spasial melalui statistik uji Moran $I$ dengan tingkat kesalahan $\alpha=0,05$. Pada uji Moran I didapatkan nilai stastistik sebesar 2,1429 dan $p$-value sebesar 0,03212. Dari hal ini dapat diartikan bahwa $p$-value dari statistik uji Moran I kecil dari $\alpha=0,05$. Dapat disimpulkan bahwa pada data penderita penyakit DBD terjadi autokorelasi spasial. Apabila pada data yang terjadi autokorelasi spasial dimodelkan dengan menggunakan metode OLS maka, akan menghasilkan model yang kurang tepat. Sehingga digunakan metode lain untuk memodelkan data tersebut yaitu dengan metode analisis regresi spasial lag. 


\subsection{Regresi Spasial Lag}

Regresi spasial lag adalah model regresi yang melibatkan peubah lag spasial dependent. Didapatkan model Spasial lag sebagai berikut :

$$
\begin{aligned}
\mathbf{y}= & -405,968+0,232893 \mathbf{W} \mathbf{y}-0.0000078 \mathbf{x}_{1}+7,99877 \mathbf{x}_{2}+3,08 \mathbf{x}_{3} \\
& +2,49109 \mathbf{x}_{4}+0,0714093 \mathbf{x}_{5} .
\end{aligned}
$$

Tabel 1. Uji Parameter Regresi Spasial Lag

\begin{tabular}{|l|l|l|l|l|}
\hline Variabel & Koofisien & Std.Error & Nilai Z & P-value \\
\hline$\rho$ & 0,232893 & 0,129854 & 1,7935 & 0,07289 \\
\hline Konstanta & $-405,968$ & 97,4685 & $-4,16512$ & 0,00003 \\
\hline Kepadatan Penduduk $\left(X_{1}\right)$ & $-0,0000078$ & 0,0334249 & $-0,000235$ & 0,99981 \\
\hline Tingkt Kemiskinan $\left(X_{2}\right)$ & 7,99877 & 1,08079 & 7,40088 & 0,00000 \\
\hline Perilaku Hidup Bersih $\left(X_{3}\right)$ & 3,08366 & 1,67812 & 1,83758 & 0,06613 \\
\hline Akses Sanitasi $\left(X_{4}\right)$ & 2,49109 & 1,16543 & 2,13748 & 0,03256 \\
\hline Efisiensi Jumlah Puskesmas $\left(X_{5}\right)$ & 0,0714093 & 0,379506 & 0,188164 & 0,85075 \\
\hline
\end{tabular}

Pada model regresi spasial lag ini dalam pengambilan keputusan digunakan $\alpha$ $=0.1$. Dapat kita lihat pada Tabel 1 untuk beberapa faktor penyebab penyakit DBD untuk daerah Sumatera Utara pada tahun 2016. Dapat disimpulkan untuk kepadatan penduduk $\left(x_{1}\right)$ dan efisiensi jumlah puskesmas $\left(x_{5}\right)$ dikatakan bahwa peubah tidak signifikan secara statistik karena nilai dari $p$ - value kedua variabel ini lebih besar dari $\alpha=0,1$. Ini menunjukkan bahwa faktor kepadatan penduduk dan efisiensi jumlah puskesmas kurang begitu berpengaruh terhadap penyebaran penyakit DBD di daerah Sumatera Utara pada tahun 2016.

Sedangkan untuk persentase kemiskinan $\left(x_{2}\right)$, persentase hidup bersih $\left(x_{3}\right)$ dan akses sanitasi $\left(x_{4}\right)$, peubah konstan signifikan secara statistik dikarnakan $p$-value dari setiap variabel $<0,1$ atau mendekati 0,1 . Ini dapat menunjukkan bahwa untuk faktor persentase kemiskinan, hidup bersih dan akses sanitasi memberikan pengaruh yang signifikan terhadap penyebaran penderita DBD untuk daerah Sumatra Utara tahun 2016. Dan dapat kita lihat juga bahwa koefisien ketetanggaan antara lokasi $(\rho)$ juga berpengruh signifikan dimana nilai $p$-value nya $0,07289<0,1=\alpha$. Ini menunjukkan bahwa terdapat hubungan antara masing-masing lokasi.

Dimodelkan kembali regresi spasial lag dengan menggunakan variabel-variabel yang berpengaruh secara signifikan terhadap jumlah penderita penyakit DBD di daerah Sumatera Utara pada tahun 2016. Didapatkan model regresi spasial sebagai berikut:

$$
\mathbf{y}=-412,053+0,246971 \mathbf{W} \mathbf{y}+7,91774 \mathbf{x}_{2}+2,59216 \mathbf{x}_{3}+3,23628 \mathbf{x}_{4} .
$$

Pada model dapat dijelaskan bahwa jika nilai pada $X_{2}$ naik $1 \%$ maka banyak penderita DBD di daerah tersebut akan bertambah 7,91774 orang, jika nilai pada $X_{3}$ naik $1 \%$ maka banyak penderita DBD di daerah tersebut akan bertambah 2,59216 orang dan pada nilai $X_{4}$ naik $1 \%$ maka banyak penderita DBD di daerah tersebut akan bertambah 3,23628 orang. Jika penderita DBD di suatu daerah bertambah 1 
Tabel 2. Uji Parameter Regresi Spasial Lag

\begin{tabular}{|l|l|l|l|l|}
\hline Variabel & Koofisien & Std.Error & Nilai Z & P-value \\
\hline$\rho$ & 0,246971 & 0,111693 & 2,21115 & 0,02702 \\
\hline Konstanta & $-412,053$ & 91,9915 & $-4,47925$ & 0,00001 \\
\hline Pesentase Kemiskinan $\left(X_{2}\right)$ & 7,91774 & 0,743649 & 10,6471 & 0,00000 \\
\hline Perilaku Hidup Bersih $\left(X_{3}\right)$ & 3,23628 & 1,59307 & 2,03147 & 0,04221 \\
\hline Akses Sanitasi $\left(X_{4}\right)$ & 2,59216 & 1,09101 & 2,37593 & 0,01750 \\
\hline
\end{tabular}

orang, maka hal ini akan menambah jumlah penderita DBD di daerah-daerah yang bertetangga dengannya sebesar 0,246971 orang.

\section{Kesimpulan}

Pada penelitian ini dapat disimpulkan bahwa:

(1) Pada pengujian autokorelasi model regresi spasial lag dengan menggunakan statistik uji Moran didapatkan nilai $p$ - value pada Moran I sebesar 0,04866 lebih kecil dari $\alpha=0,05$. Ini menunjukkan bahwa terjadinya autokorelasi spasial pada data penyakit demam berdarah Dengue(DBD) didaerah Sumatra Utara pada tahun 2016.

(2) Model regresi spasial lag yang didapatkan pada penyebaran penyakit DBD di daerah Sumatera Utara tahun 2016 adalah:

$$
y=-412,053+0,246971 \mathbf{W} y+7,91774 x_{2}+2,59216 x_{3}+3,23628 x_{4} .
$$

Ini menunjukkan bahwa pada setiap variabel berhubungan positif terhadap penderita DBD. Jika pada persentase kemiskinan naik $1 \%$ maka banyak penderita DBD di daerah tersebut akan bertambah 7,91774 orang, pada persentase perilaku hidup bersih naik $1 \%$ maka banyak penderita DBD di daerah tersebut akan bertambah 2,59216 orang dan pada persentase akses sanitasi naik 1\% maka banyak penderita DBD di daerah tersebut akan bertambah 3,23628 orang. Jika penderita DBD di suatu daerah bertambah 1 orang, maka hal ini akan menambah jumlah penderita DBD di daerah-daerah yang bertetangga dengannya sebesar 0,246971 orang

\section{Ucapan Terimakasih}

Penulis mengucapkan terima kasih kepada bapak Dr. Dodi Devianto, ibu Dr. Shelvi Ekariani dan bapak Budi Rudianto, M.Si yang telah memberikan masukan dan saran sehingga makalah ini dapat diselesaikan dengan baik.

\section{Daftar Pustaka}

[1] Anselin, L. 1988. Spatial Econometrics: Methods and Models. London:kluwer Academic Press.

[2] Anselin, L. 2000. Geoda Spatial Regression. http : //www.s4.brown.Edu/S4/ about.htm. Diakses pada tanggal 1 maret 2018. 
66 Evan Ilham Zulheri dkk

[3] Anselin, A. 2003. An Introduction to Spatial Regression Analysis in $R$. http//sal.uiuc.ede/shuff-sum/pdf/spdeintro.pdf. diakses pada tanggal 1 maret 2018

[4] Pagalay, U. 2009. Mathematical Modelling. Malang:UIN Malang Press.

[5] LeSage, J.P.. 1999. The Theory and Practice of Spatial Economitrics. New York:University of Toledo.

[6] Supangat, A.. 2007. Statistika Dalam Kajian Deskriptif, Inferensi dan Nonparametrik. Jakarta:Kencana Prenada Media Grup.

[7] Sembiring, R.K. Analisis Regresi. (Edisi II, Bandung: Penerbit ITB:1995).

[8] Karra, M. Statistik ekonomi (Makassar: Alauddin University Press).

[9] Algifari, Analisis Regresi: Teori, Kasus, dan Solusi. (Edisi Kedua, Cetakan ke-4, Yogyakarta: BPFE:2013).

[10] Suprapto, J. 2004. Ekonometrik, Jakarta: Ghalia indonesia.

[11] Kosfeld, R. Spatial Econometrics (URL:http//www.scribd.com ,2006) 